\title{
Waste management and their environmental impact: Challenges and opportunities at national level
}

https://doi.org/10.21698/rjeec.2020.108

Review

\author{
LIDIA KIM, GEORGETA MADALINA ARAMA*, GHEORGHE BATRINESCU, MIHAI \\ BRATU, AGNES SERBANESCU, CAROL BLAZIU LEHR
}

National Research and Development Institute for Industrial Ecology - ECOIND, 71-73 Drumul Podul Dambovitei Street, 060652, Bucharest, *madalina.arama@incdecoind.ro., Romania.

\begin{abstract}
Both nationally and globally, waste generation increases with increasing product consumption. Thus, addressing the issue of waste is an ongoing challenge for researchers around the world. This challenge derives from the fact that in many European countries, including Romania, the amount of waste generated is very high compared to current technologies for treatment, recycle or recovery. Therefore, the most convenient management methods remain storage and incineration. These methods generate significant amounts of hazardous pollutants with a significant impact on the environment and human health. The paper presents a series of results related to waste management obtained within National Research and Development Institute for Industrial Ecology - ECOIND Bucharest in the last 10 years. The paper is focused on four topics: analytical detection and monitoring of waste pollutants; environmental impact and risk assessments; harmonized waste classification and management; waste treatment and recovery technologies. The results obtained within these topics refers to optimal methods for detection and characterization of complex waste matrices, methods for assessing the impact on the environment generated by non-compliant landfills and risk prediction and reliable solutions and technologies for waste treatment and recovery. The topics approached represent a challenge for starting the implementation of circular economy concept promoted by EU and adopted by countries and governments all over the world.
\end{abstract}

Keywords: environment, management, monitoring, technologies, waste

\section{INTRODUCTION}

As a result of the increasing amount of continuously generated waste, their management is a challenge both at national and global level. As a consequence, the European legislation created a legal framework to start a harmonized waste classification for their further efficient and ecological management [1-6]. Industrial symbioses and academic partnerships have been encouraged to create the premises of implementation of circular economy. Specialists from different areas such as ecology, engineering, chemistry, biology, regulatory/ governmental bodies and agencies started to work together in order to find viable waste management solutions. However, there are a lot of uncertainties about how pollution on different environment segments can evolve over time [79]. Numerous ongoing research studies are being conducted on how the limits for the discharged environmental pollutants for air, soil and surface water segments should be set. However, the issue of waste management related to the environmental and human health protection is far from being resolved. [10-13]. Consequently, the best protective practices direct actually towards minimization of waste volumes to be disposed. Research in recent years on waste management has been carried out in accordance with national and European waste environmental legislation. Thus, in the context of sustainable development, according with Law 211 of 2011 on waste management, they should be managed applying the principle of waste hierarchy. First of all, according to this principle, the generation of waste should be avoided through good design and manufacturing practices. Second, if possible, any valuable component should be recovered for energy or non-energy uses. Lastly, there is the management of waste by disposal after appropriate pre-treatment/treatment, if necessary, in the context of maximum protection of the environment and human health. These represent ongoing challenges for the scientific community and are the prerequisites for starting to implement the concept of circular economy. Another challenge in the waste management field is the harmonized classification of waste according to the presence/absence of substances 
that confer hazardous properties to the waste. For the classification of waste, special attention shall be paid to the hazard statements of waste components defined in accordance with EU Regulation 1272/2008. Those components can induce hazardous properties HP $1 \div \mathrm{HP} 15$ to the waste when exceeding certain limits of concentrations as stated in the Directive 98/2008 Annex III with revisions, transposed in the Romanian legislation by the law L 211/2011 with updates [3, 4, 14]. Based on those aspects, our research activities in the last decade have been dedicated to improvements of the analyses, techniques, methods and methodologies linked to the waste management and their environmental impacts. In order to find good practical management solutions, research studies on the following topics have been developed: waste pollutants analytical detection and monitoring; environmental impact and risk assessments; harmonized waste classification and management; waste treatment and recovery technologies (Figure 1).

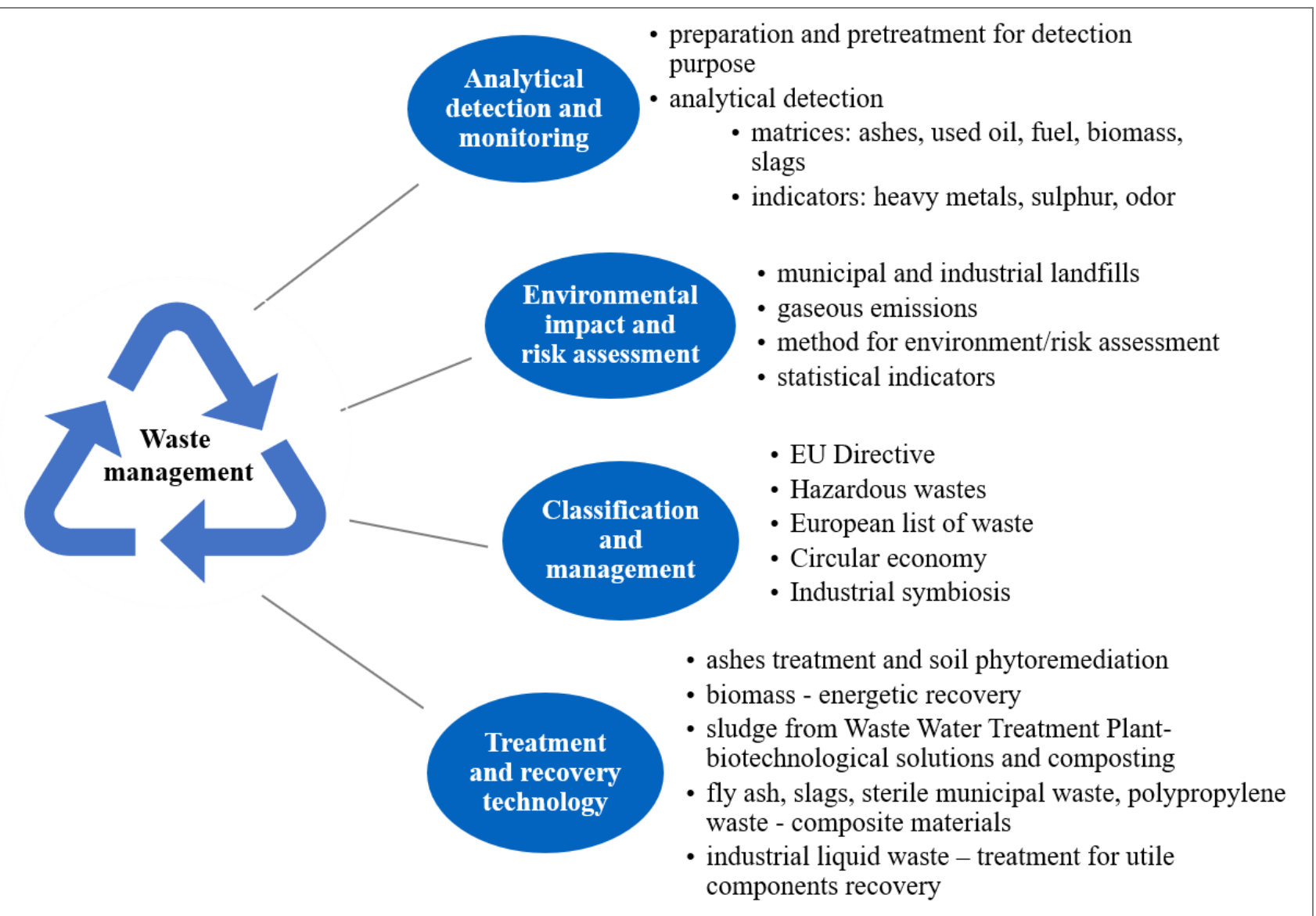

Fig. 1. The topics presented in the paper

\section{International and national trend of studies on waste - Web of Science Platform}

According to the Clarivate ISI Web of present in the title of the article: "waste Knowledge - Web of Science Platform, more than 13,000 publications approaching waste topics waste have been identified in the last 10 years. Figures 2-7 show the evolution of the number of articles published in the platform on management"; "waste detection"; "waste monitoring"; "waste risk"; waste environmental impact"; "waste classification"; "waste symbiosis"; "waste treatment"; "waste each topic. The search was made by keywords 


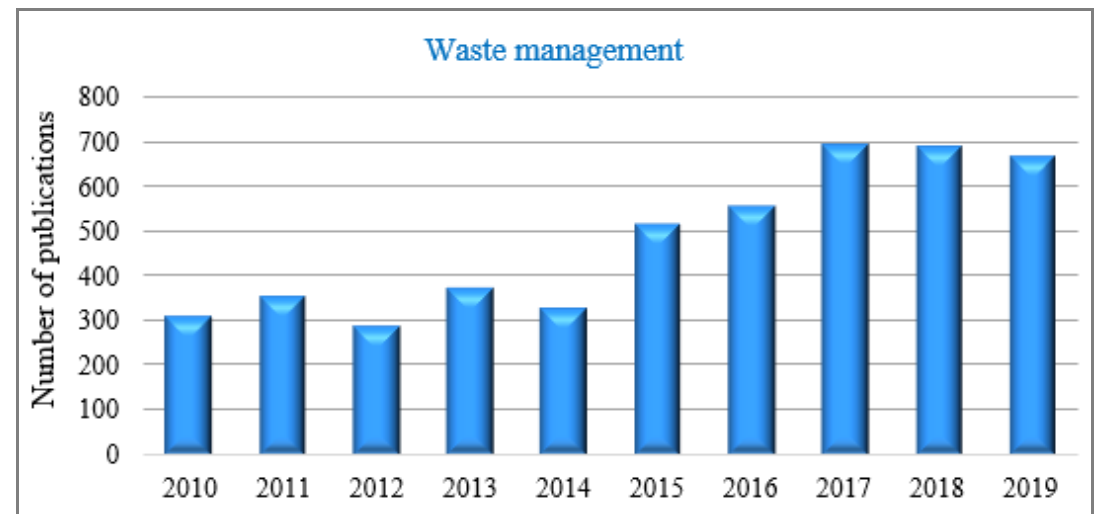

Fig. 2. Trend of waste management studies - Web of Science Platform

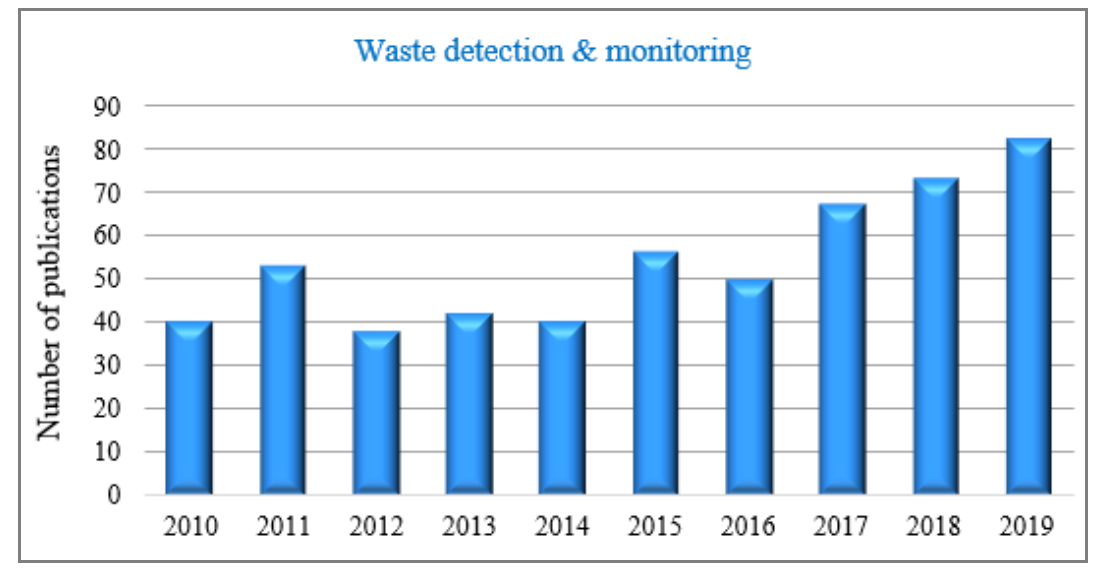

Fig. 3. Trend of waste detection \& monitoring - Web of Science Platform

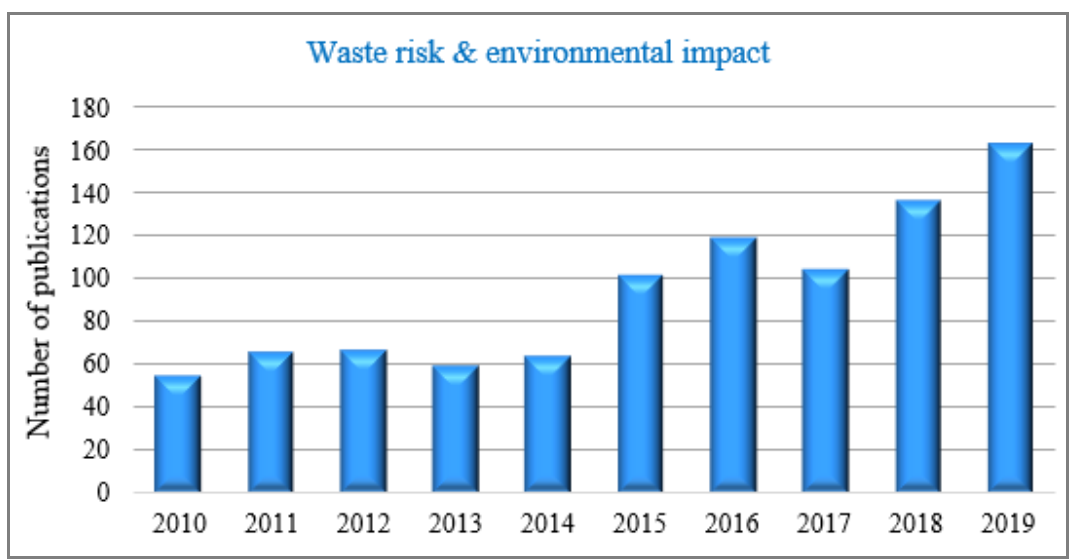

Fig. 4. Trend of waste risk \& environmental impact - Web of Science Platform

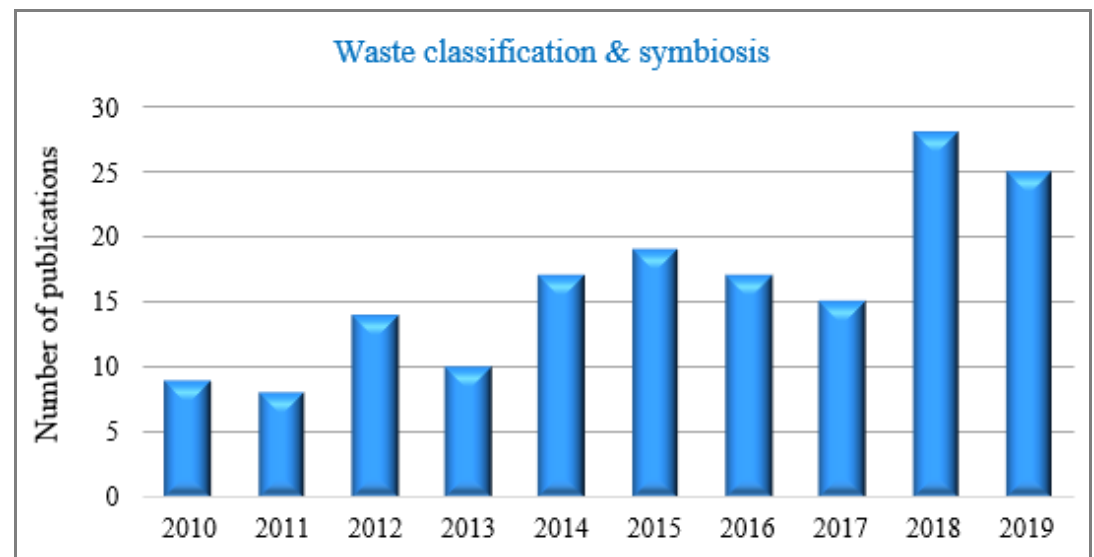

Fig. 5. Trend of waste classification \& symbiosis - Web of Science Platform 


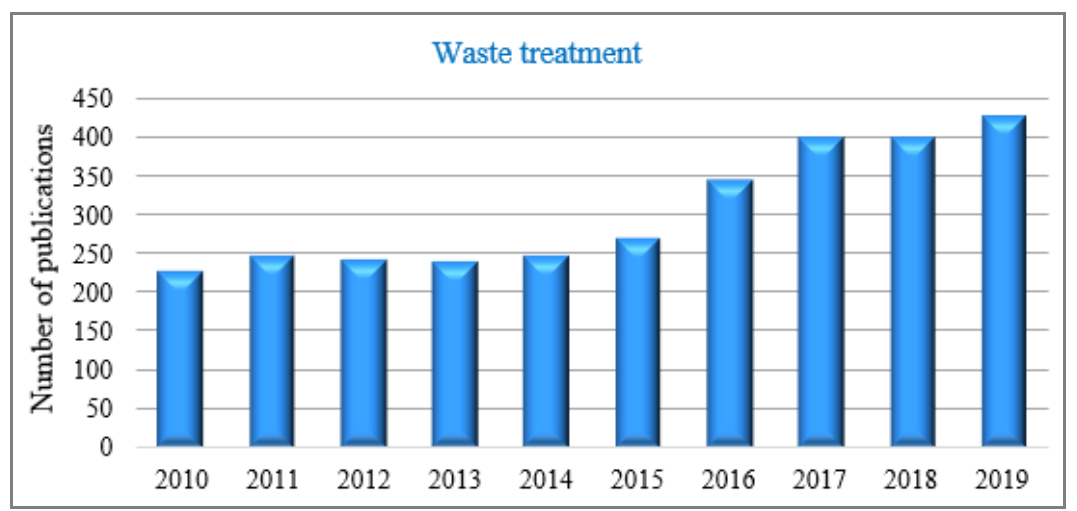

Fig. 6. Trend of waste treatment - Web of Science Platform

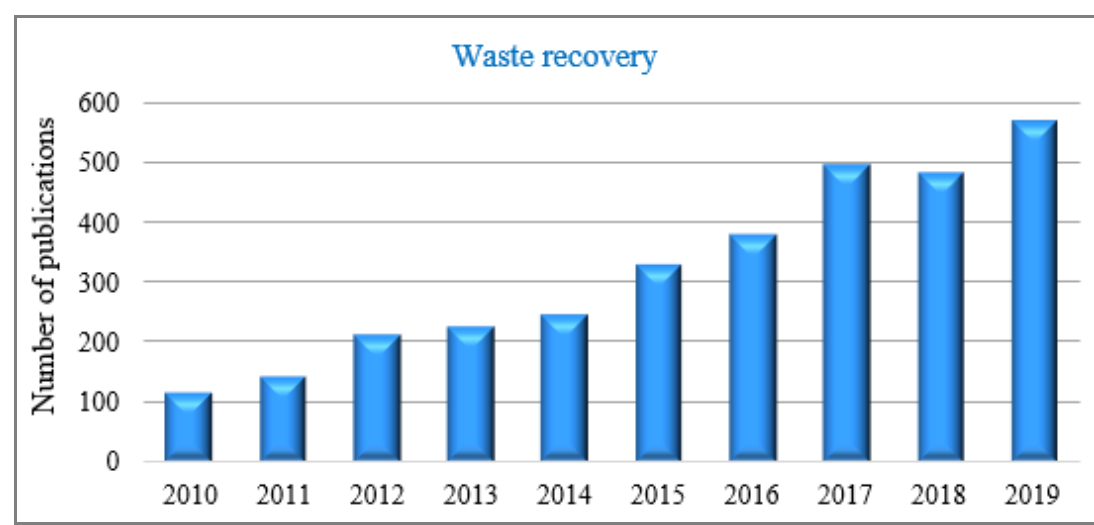

Fig. 7. Trend of waste recovery - Web of Science Platform

Figures 2-7 show an increase in the number of countries in this field (Figure 8). Thus, the need publications in the last 10 years on each topic, to intensify studies in the field of waste becomes most articles being focused on waste an emergent necessity considering both the management, treatment and recovery. $\quad$ rigorous impositions of European Directives and At national level there are few studies conducted the impact induced on the environment by the in the field of waste, Romania being at the quantities of waste that are constantly growing. bottom of the ranking among European

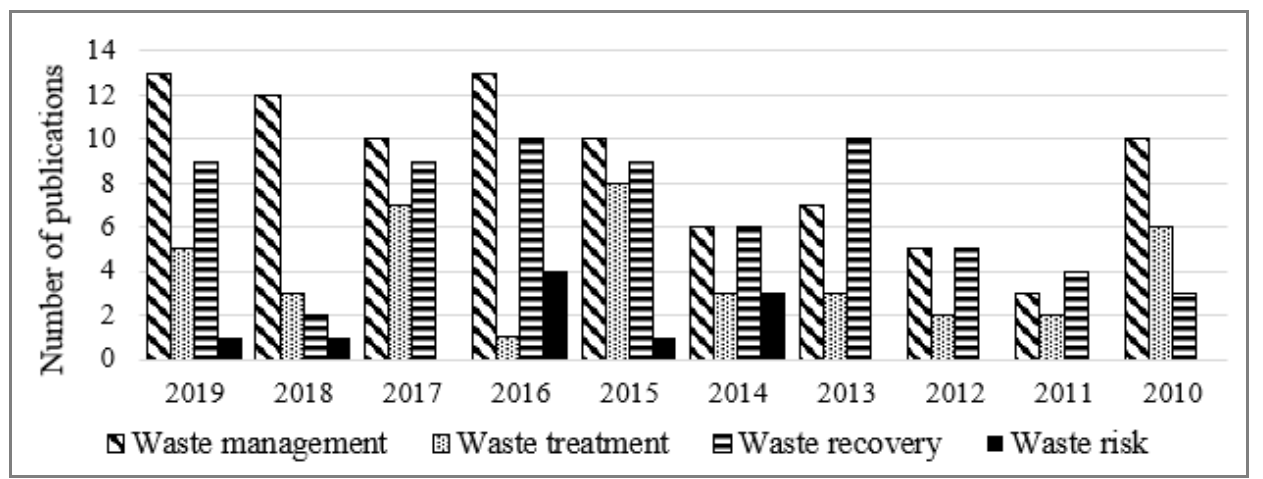

Fig. 8. Trend of studies on waste at national level - Web of Science Platform

\section{RESULTS AND DISCUSSION}

\section{Waste pollutants analytical detection and monitoring}

The composition of waste is changing rapidly others to the sample matrix complexity and with new production technologies, from which various waste matrices are generated. Analytical detection and monitoring of pollutants from heterogeneity. These have a significant impact on uncertainty of final detection results. Any waste have some specific issues linked among activities should have a clear methodology for 
samples collection, preservation and processing according to the waste characteristics [15]. The indicators must to be analyzed by using recommended/accepted standards and norms in the field, in order to ensure reliable and comparable test results. The established testing program according to standards in the field, for example SR EN 16457:2014, should ensure good coordination of field and laboratory activities [16]. The high heterogeneity of the waste sample has consequences on mass balances closures for analytical results reporting. For liquid waste, the specialists in the field agree for mass balance closure to be around $90 \%$ w/w not $100 \% \mathrm{w} / \mathrm{w}$ [17]. In the same idea, for solid wastes, the sum of determined constituent concentrations will be reported on dry matter in a range of $90 \div 110 \% \mathrm{w} / \mathrm{w}$. According to the current law, in the analytical test reports, for final classification decision purposes, the concentration of wet wastes that includes the water content will be used as computation reference. Issues related to samples preparation and processing of waste will be presented next. Some practical solutions were found for accurate determinations of different monitoring indicators from different waste matrices. Among a variety of environmental waste pollutants to be determined, a special case is represented by heavy metals. They are largely found in different liquid, solid and gaseous waste flows and they are not degraded in the environment but they only transform [18]. That is exactly why a good deal of the research in the pollutants detection and monitoring area has been focused towards monitoring heavy metals emissions from different kind of waste types (class)/categories (groups) to find the most adequate procedures for preparation and processing of metal containing waste samples. Starting from those aspects, relevant results for assessment and characterization of metal fractions in bottom and filter ashes from medical waste incineration using two different sequential extraction methods were obtained [19]. To assess metal toxicity in the leaching process it was used TCLP test (Toxicity Characteristic Leaching Procedure). In both types of ashes, the metals are predominantly bounded in exchangeable and iron and manganese oxides fractions. While in bottom ash the metal concentrations are in the range of tens to hundreds of $\mathrm{mg} / \mathrm{Kg}$ (e.g. 180 $\mathrm{mg} / \mathrm{kg}$ ) in filtered ash, the concentrations are found in the range from hundreds to thousands of $\mathrm{mg} / \mathrm{Kg}(1,300 \mathrm{mg} / \mathrm{kg})$. In filter ash, due to high concentrations of $\mathrm{Cu}, \mathrm{Cr}, \mathrm{Pb}$ and $\mathrm{Zn}$ in exchangeable forms, a special attention should be given when manage such waste, in order to avoid heavy metals dispersion in environment segments. Even if the wastes are classified under the same harmonized code, the heavy metals content is different from one matrix to another depending on the generation process. Thus, some research studies focused to set some experimental models for the characterization and analysis of waste samples coming from the same type/class of waste [20]. The experimental models were applied on the metals analysis in four wastes coming from processing and finishing activities of metal surfaces and other materials. For organic matter decomposition were used four digestion methods. Metal concentrations have been analyzed by AAS (Atomic Absorption Spectrometry) and XRF (XRay Fluorescence Spectrometry) to show their influence on the final analytical results. From obtained results was found that, there are very high differences in concentrations between the matrices of wastes analyzed. Despite this fact, the mineralization using method IV is the one that responded well in both low and high levels of metals. The proposed experimental models can be successfully applied in the usual laboratory practice to characterize different groups/categories of wastes from European list of waste. In the same context were developed adequate digestion methods for metal determination in biomass wastes coming from agriculture, forestry, horticulture, and wine industry [21]. For biomass waste mineralization have been used two types of digestion methods. The metals were analyzed by AAS (Atomic Absorption Spectrometry) and ICP-MS (Inductively Coupled Plasma-Mass Spectrometry) in order to demonstrate the quality of the obtained results in terms of detection limits, precision, accuracy and extended uncertainty. The authors concluded that for the matrices of biomass waste, reproducible results have been obtained by using microwave digestion and metals determination by ICP-MS. Another important parameter besides the waste matrix is waste sample homogeneity as we have already mentioned. 
Other researchers reported results on the statistical evaluation of experimental determinations for gross calorific value and carbon content indicators [22]. The research was realized to set the necessary degree of samples homogeneity prepared from mixed solid wastes used in the current laboratory determinations. It is known that the accuracy of those determinations is directly involved in the safety of combustion and environmental protection in relation with gaseous emissions. In relation with this topic another important parameter for the environment and human health that should be accurately determined from the waste/waste mixture intended for incineration is Sulphur content. Among other determination methods of Sulphur from waste mixtures, one method of choice might be ion-chromatography method [23]. The research has been done on Refused Derived Fuel resulting from municipal waste. From experimental tests it is observed that "the ion-chromatographic method gives similar results with the more frequently used gravimetric method. In addition, this method has advantage of being faster and giving more homogenous results.

Table 1. Waste - analytical detection and monitoring

\begin{tabular}{|c|c|c|c|c|c|}
\hline Matrices & Analytical procedures & Analytes & $\begin{array}{l}\text { Detection } \\
\text { technique }\end{array}$ & Aims & Ref. \\
\hline $\begin{array}{l}\text { Fly ash; } \\
\text { Bottom ash }\end{array}$ & $\begin{array}{c}\text { Comparative } \\
\text { sequential extraction procedures } \\
\mathrm{BCR} \text { - classic method: shaking time } 16 \mathrm{~h} \\
\text { followed by centrifugation; } \\
\mathrm{BCR}-\text { modified } \\
\text { method: sonication } \\
\text { time } 30 \text { min followed } \\
\text { by centrifugation }\end{array}$ & $\begin{array}{l}\mathrm{Cr}, \mathrm{Cu}, \mathrm{Ni}, \mathrm{Zn}, \\
\quad \mathrm{Pb}, \mathrm{As}, \mathrm{Cd}\end{array}$ & ICP-MS & $\begin{array}{l}\text { Assessment mobile } \\
\text { fraction from ashes }\end{array}$ & [19] \\
\hline $\begin{array}{l}\text { Fly ash; } \\
\text { Bottom ash }\end{array}$ & $\begin{array}{c}\text { Toxicity characteristic leaching procedure } \\
\text { test }(T C L P)\end{array}$ & $\begin{array}{l}\mathrm{Cr}, \mathrm{Cu}, \mathrm{Ni}, \mathrm{Zn}, \\
\quad \mathrm{Pb}, \mathrm{As}, \mathrm{Cd}\end{array}$ & ICP-MS & $\begin{array}{l}\text { TCLP test is using to } \\
\text { confirm toxicity for } \\
\text { metals in exchangeable } \\
\text { form }\end{array}$ & [19] \\
\hline $\begin{array}{l}\text { Soil and filter } \\
\text { cakes; } \\
\text { Powder } \\
\text { coating } \\
\text { waste; } \\
\text { Paint waste }\end{array}$ & $\begin{array}{c}\text { For decomposition organic matter were } \\
\text { using four mineralization } \\
\text { methods: I. } \mathrm{HNO}_{3} \\
\text { II. } \mathrm{HNO}_{3}+\mathrm{HCl} \\
\text { III. } \mathrm{HNO}_{3}+\mathrm{H}_{2} \mathrm{O}_{2} \\
\text { IV. } \mathrm{HNO}_{3}+\mathrm{H}_{2} \mathrm{O}_{2}+\mathrm{HCl}\end{array}$ & $\mathrm{Cu}, \mathrm{Zn}, \mathrm{Ni}, \mathrm{Pb}$ & $\begin{array}{l}\text { AAS } \\
\text { XRF }\end{array}$ & $\begin{array}{l}\text { Characterization of } \\
\text { waste with complex } \\
\text { matrices }\end{array}$ & [20] \\
\hline $\begin{array}{l}\text { Biomass } \\
\text { waste }\end{array}$ & $\begin{array}{c}\text { Comparative digestion methods } \\
\text { Closed system - microwave oven: } 0,25 \mathrm{~g} \\
\text { sample, } 2 \mathrm{~mL} \mathrm{H}_{2} \mathrm{O}_{2}+8 \mathrm{~mL} \text { of } \mathrm{HNO}_{3} \text { for } 15 \\
\text { minutes at } 180^{\circ} \mathrm{C} \text {; } \\
\text { Open system - sand bath: } 1 \mathrm{~g} \text { sample, } 2 \mathrm{~mL} \\
\mathrm{H}_{2} \mathrm{O}_{2}+8 \mathrm{~mL} \text { of } \mathrm{HNO}_{3} \text { for } 90 \text { minutes at } \\
120^{\circ} \mathrm{C} \\
\text {-Sample preparation by particles size }\end{array}$ & $\begin{array}{l}\mathrm{Al}, \mathrm{Mg}, \mathrm{K}, \mathrm{Ca} \\
\mathrm{Na}, \mathrm{Fe}\end{array}$ & $\begin{array}{l}\text { ICP-MS } \\
\text { AAS }\end{array}$ & $\begin{array}{l}\text { Find an appropriate } \\
\text { method for } \\
\text { characterization the } \\
\text { biomass wastes }\end{array}$ & [21] \\
\hline $\begin{array}{l}\text { Solid waste } \\
\text { (mixture of } \\
\text { biomass, } \\
\text { textile and } \\
\text { plastic) }\end{array}$ & $\begin{array}{c}\text {-Sample preparation by particles size } \\
\text { reduction: } \\
\text { Ash content and calorific value } \\
\text { determination - particles size below } 1 \mathrm{~mm} \text {; } \\
\text { Carbon content determination - } \\
\text { particle size between } \\
0.2 \mathrm{~mm}-0.5 \mathrm{~mm} \\
\text {-Samples homogenization }\end{array}$ & $\begin{array}{l}\text { Gross calorific } \\
\text { Carbon } \\
\text { content }\end{array}$ & $\begin{array}{l}\text { Calorimetry } \\
\text { Elemental } \\
\text { analysis }\end{array}$ & $\begin{array}{l}\text { Influence of } \\
\text { homogeneity in } \\
\text { analytical } \\
\text { determinations }\end{array}$ & [22] \\
\hline $\begin{array}{c}\text { RDF } \\
\text { (Refuse- } \\
\text { Derived } \\
\text { Fuel); } \\
\text { Textiles and } \\
\text { paper; } \\
\text { Sewage- } \\
\text { sludge; } \\
\text { Oil-sludge }\end{array}$ & $\begin{array}{l}\text { Comparative determination methods } \\
\text { Ion-Chromatographic - performance method } \\
\text { Gravimetric - classic method }\end{array}$ & Sulfur content & $\begin{array}{c}\mathrm{IC} \\
\text { technique }\end{array}$ & $\begin{array}{l}\text { Find a faster method for } \\
\text { determination of sulfur } \\
\text { content }\end{array}$ & [23] \\
\hline
\end{tabular}




\section{Environmental impact and risk assessments}

The identification of pollution that leads to a significant impact on the environment, is followed by a risk assessment to take the necessary measures to mitigate it. Monitoring the pollution of air, soil, subsoil, surface water and groundwater near municipal and industrial landfills is a very important environmental topic. The specialized literature presents numerous studies in this field [24-26]. Air pollution can be perceived in the vicinity of industrial pollutants by unpleasant atmosphere and unpleasant odor. There may also be many dangerous compounds imperceptible in high concentrations [27]. Therefore, both perceived harmful odors and imperceptible hazardous compounds should be continuously monitored both at the source and in neighboring areas. Nuisance odors control is usually accomplished in industrial settings by gas scrubbing with wet scrubbers or by controlling conditions in anaerobic facilities in such a way that hydrogen sulfide will not be released [24-26]. In those conditions the air monitoring pollutants is becoming a stringent necessity. In many cities across Romania, landfills are placed very close to settlements, and in some cases even inside cities. Besides landfill activities, other companies that deal with waste sorting, recycling and treatment operates nearby. Related to this topic, relevant results of monitoring of odors near a landfill were obtained [28]. The research was directed towards monitoring of $\mathrm{NH}_{3}, \mathrm{H}_{2} \mathrm{~S}$ and $\mathrm{VOC}$ in order to impact assessment of landfill situated in high urbanization area. Odor level was determined according to SR EN 13725:2003 using dynamic olfactometry method. For the impact assessment and annoyance level were using FIDOL factors such as Frequency, Intensity, Duration, Offensiveness and Location. From obtained results, it is found that high values were recorded both for chemical measurements and odor level. The results showed a significant impact on the air due to landfill site and other connected activities. Next are presented some relevant research related to atmospheric pollution with gaseous emissions near non-compliant landfills [29-30]. These research studies were realized in the context of future residential developments in the vicinity of those landfills. Two municipal waste landfills situated in the West of Bucharest and in Suceava county have been investigated. Thus, several campaigns of investigation have been running for gases emissions from soil/subsoil areas situated in their neighborhoods. In order to estimate the risk components (probability and severity of consequences) two specific methodological approaches have been used. The conclusions of the study show that for the landfill located in the western part of Bucharest, even after 20 years from the landfill works closure there are different ways of migration of gaseous emissions. These emissions are influenced by anthropogenic factors such as excavation activities, the position of pipelines routes and cracks. For the landfill located in Suceava County, low concentrations of methane $(0.4 \%)$ were found. However, the concentrations cannot exclude the possibility of gas migration in the vicinity of the deposit. For both evaluated landfills, the sedimentary lithology of the area is permeable, thus favoring the migration of gases in the soil / subsoil. The ground and surface waters pollution has been also the topic of investigation in Bucharest - Giulesti Sarbi area near a landfill site [31]. The research revealed the existence of a pollution able to induce a high risk for those environmental segments. Also, another zone located near the municipal waste landfill in Targu Neamt revealed the adverse effects of landfill levigates on the quality of groundwater [32]. Over last decades, in rainy periods, the levigates from municipal waste discharged directly in torrent valley generating degradation of the Slatina river quality. These discharges caused acute toxic effects on aquatic ecosystem inducing a significant environmental impact. Following those findings, adequate mitigation measures have been recommended. Another study referring to environmental risk assessment for a landfill located in Region NW of Romania in the vicinity of Cluj-Napoca was performed [33]. To assess the environmental risk, a conceptual assessment model was proposed and sampling campaigns were established for air, groundwater, soil and leachate samples from both the landfill and its immediate vicinity. Quantification of the risk according to the results obtained indicates a significant risk of environmental pollution even after cessation of activity, a risk that requires immediate mitigation actions. Another research 
study refers to the characteristics of groundwater in a mining area with an activity over 30 years. The study focused on the spatial-temporal evolution of heavy metal concentrations in groundwater. The investigation area was established next to a waterproofed pond located next to two other sterile mining tailings ponds [34]. The hydro-observation wells were monitored in three seasonal investigation campaigns. The obtained results showed that the groundwater is contaminated with heavy metals, the highest concentrations being recorded for $\mathrm{Fe}$, $\mathrm{Cd}, \mathrm{Mn}$ and $\mathrm{Pb}$. Regarding the investigation period, for all hydro-observation wells, high concentrations were registered in the spring campaign. This may be due to the rich seasonal precipitation that led to the dissolution of the metals. A good environmental impact and risk assessment requires good and reliable decision methods. In this respect, in the latest years our research have been also directed towards the development of reliable multi-criterial decision methods for environmental impact/risk assessments based on Dempster-Shafer, Evidential Reasoning algorithm, Rough Set Theory, Fuzzy Set Theory and Analytical Hierarchy Process [35-43]. Those methods are useful instruments that help to structure high volume of data and information encountered in the practical applications. Those methods can be useful also "when statistical data are missing or are too costly". Using subjective probability and assessment with linguistic attributes can be effectively used with them. These assessments help evaluators to report much easier the obtained risk assessment results to the interested parties. A multicriterial method for environmental risk assessment for the landfill waste is proposed [44]. The method tries to synthesize the most important criteria of interest to predict possible pollution and its consequences. Thus, the method offers a good decision support instrument for environmental risk mitigation measures. Good decision support instruments are of particular importance to set a sustainable development strategy. It is known that, in last decades both at national and world level there is a significant pollution due to waste generation. Thus, a lot of research activities have been focused on finding indicators that can decouple the economic growth from the excessive resources consumption especially those that are non-renewable or hard renewable ones. In this context, it was developed a methodology that underlies a system of statistical indicators that can be used to illustrate the environmental pressure that comes from economic development [45]. These indicators are calculated by relating the amount of hazardous / non-hazardous waste generated at the level of an industrial economic activity to the value of the obtained production. Statistically indicators can be established both at the level of a specific industrial activity and also at the global level for a sector or an industrial branch. By conducting this statistical study, it can be shown that for a certain period of time the increase of environmental pressure is less than the increase of industrial economic activity. Thus, the developed indicators are a useful tool for central and local authorities, reflecting the failure or success of national economic development policies.

\section{Harmonized waste classification and management}

Harmonized waste classification is first step for the future adequate waste management. In this context, at the European level the waste management has been regulated through EC Waste Directive 98/2000 updated with EC Regulation no. 1357/2014 and EC Decision 532/2000 updated with Decision Commission $955 / 2014$, setting the rules regarding wastes classification and wastes management $[1,3,5]$.
This is done through a waste comprehensive inventory named List of Waste organized by chapters, sections and codes. Each wastes producer/holder shall scan this inventory and try to find a "best match" for the generated / held wastes for an appropriately classification. In Figure 9 is presented the general scheme for identification one waste code. 


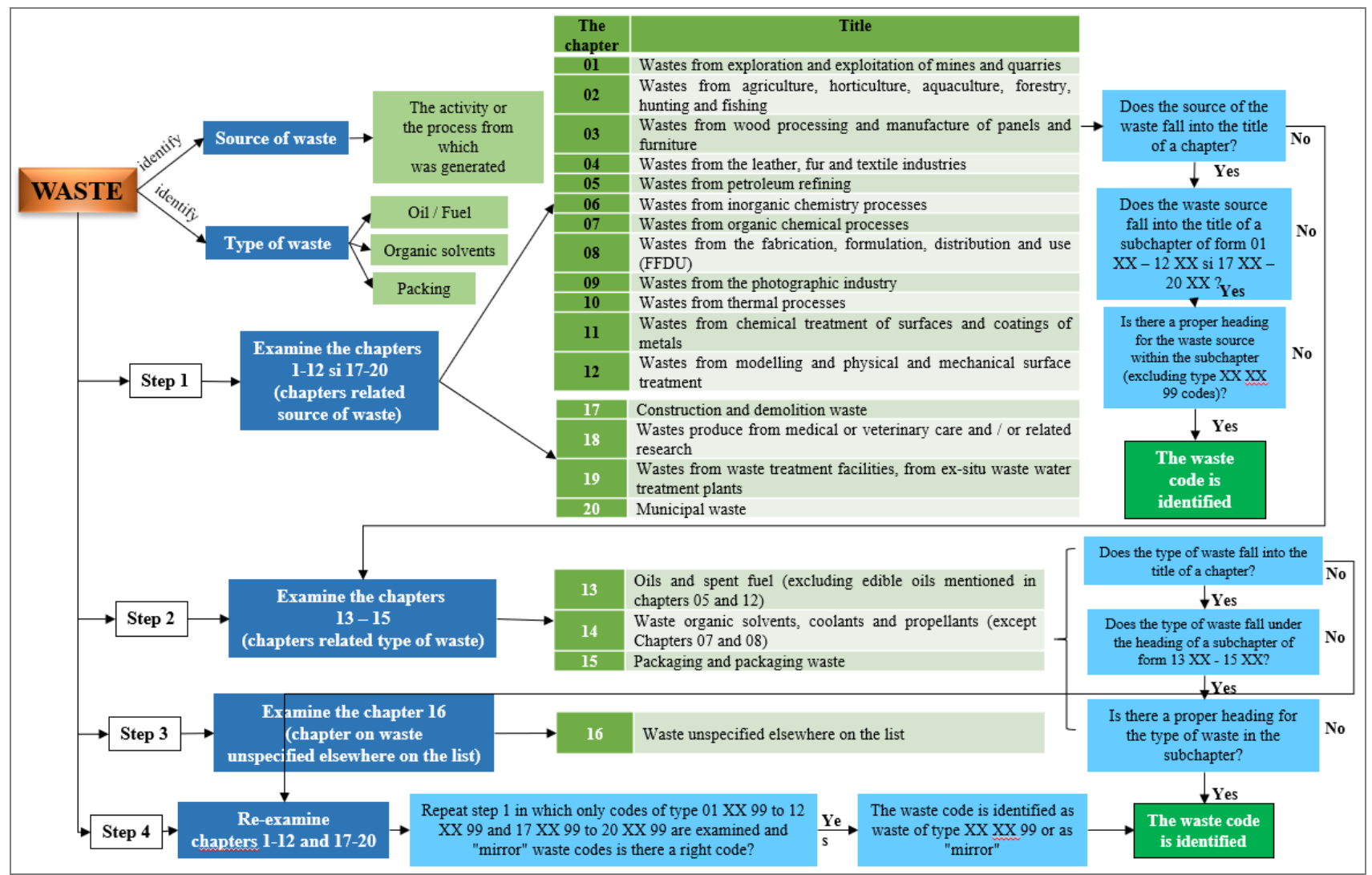

Fig. 9. General scheme for waste classification

The classification can be done under three types of wastes categories: absolute non-hazardous waste $(\mathrm{ANH})$, absolute hazardous waste $(\mathrm{AH})$ and mirror wastes - wastes that can be classified under two different codes either as mirror nonhazardous wastes $(\mathrm{MNH})$ or mirror hazardous wastes $(\mathrm{MH})$. Their classification is based on the absence or quantitative presence of substances with intrinsic hazardous statement codes that might impart to the wastes hazardous properties of type HP1 $\div$ HP 15 . In this respect, it should mention a set of published papers between 20132018 revealing efforts done to find the best methodological approaches including principles, algorithms, and procedures in order to determine hazardous properties of waste HP $1 \div$ HP 15 for a harmonized waste classification [41, 43, 46-49]. Waste classification and management represent the first step to start realize transition from a linear economy to a circular economy [8-10, 50]. The circular economy is defined as an economic system which is based on extract, produce, reuse, recycle and recovery of used materials along the product life cycle going towards the desiderate of zero waste disposal. The concept of circular economy has been promoted in recent years by the European Community and extended to countries around the world. In Romania, studies in this field are still in their infancy, but there is a potential interest in deepening the field of circular economy and industrial symbiosis. Thus, within a project financed by the European Union (ECOREG project, LIFE + program) a methodology was developed for the implementation of industrial symbiosis in several small communities in Suceava County $[51,52]$. Through industrial symbiosis, there is the possibility to increase production for economic units, without increasing the consumption of raw materials and utilities. The results showed that some 500,000 tons of biomass waste from various landfills were directed to a local chipboard producer. In addition, some $150,000 \mathrm{~m}^{3}$ of biomass waste from various landfills were directed to a local wooden briquettes manufacturer. Thus, over 600 ha of virgin forest and fossil fuels were saved. This project showed that financial, technical and economic performance can be improved by applying an industrial symbiosis. 


\section{Waste pretreatment/treatment and recovery technologies}

Waste treatment and recovery technologies are used to find different ways for waste management including recovery of useful nonenergetically and energetically components. However, when such recovery technologies cannot be applied the waste should be disposed with maximum protection for the environment and human health. Such an example is given in the study realized for bottom and filter ashes resulted from the incineration of medical waste [53]. These ashes are contaminated with heavy metals and other pollutants whose concentrations exceed maximum admissible values for the storage on hazardous waste landfills. The research was aimed the treatment of these ashes in order to dispose them on nonhazardous waste landfills. Thus, two treatment solutions were proposed: first solution was to wash them under mixing with acid solution followed by filtration and the second solution was to mix them with sand and cement and to incorporate them into concrete type matrices. The obtained results after these treatments, showed that the bottom and filter ashes can be disposed on the non-hazardous waste landfills. Also, in relation with ash type of waste one could mention that, along the years ashes from different thermal processes have been disposed in different landfills, not only in Romania but all over the world. Old landfills waste from thermal power plants operating on fossil fuel (coal) are usual in this category. The pollutants from those ashes were dispersed by rainfalls that affected environmental ecosystems. In those conditions, Romania, following the examples from other western countries targeted them for phytoremediation. In the next section are presented the possibility of reclamation of land areas that were taken out from the agricultural circuit as a result of storage of bottom and boiler slag and fly ash [54-56]. Their reintegration can be done by using a waste as biological material, e.g. sewage sludge. In Table 2 are presented some results of phytoremediation of such areas using plants species and monitoring them for bioaccumulation of heavy metals i.e. $\mathrm{Cd}, \mathrm{Cr}, \mathrm{Cu}$, $\mathrm{Ni}, \mathrm{Pb}, \mathrm{Zn}$. The success of phytoremediation is that metals particles are hampered to be spread into the environment. The phytoremediation proposes the alternative of concentrating metals in some tolerant species that can grow in this area transforming the landscape into more pleasant one.

Table 2. Phytoremediation

\begin{tabular}{|c|c|c|c|c|}
\hline Matrices & Fertilizer & $\begin{array}{l}\text { Plant for } \\
\text { remediation }\end{array}$ & Accumulated metals & Ref. \\
\hline $\begin{array}{l}\text { Contaminated } \\
\text { soil }\end{array}$ & Sewage sludge & Lolium perenne & $\begin{array}{c}\mathrm{Cu}, \mathrm{Cr}, \mathrm{Ni}, \mathrm{Zn} \text { - small amounts } \\
\mathrm{Pb} \text { - large amount }\end{array}$ & [54] \\
\hline Fly ash & $\begin{array}{c}\text { Municipal } \\
\text { sewage sludge }\end{array}$ & $\begin{array}{l}\text { Lolium Perenne } \\
\qquad(L P) \\
\text { Onobrychis } \\
\text { Viciifolia }(\mathrm{OV})\end{array}$ & $\begin{array}{l}\mathrm{Cu}, \mathrm{Cr}, \mathrm{Fe}, \mathrm{Ni}, \mathrm{Pb} \text { - the amount } \\
\text { accumulated by the two plants is similar } \\
\mathrm{Mn} \text { - Onobrychis Viciifolia accumulates } \\
\text { twice as much as Lolium Perenne } \\
\mathrm{Zn} \text { - Onobrychis Viciifolia } \text { accumulates } \\
\text { four times more than Lolium Perenne }\end{array}$ & {$[55]$} \\
\hline $\begin{array}{l}\text { Contaminated } \\
\text { soil }\end{array}$ & $\begin{array}{l}\text { Biosolid } \\
\text { fertiliser }\end{array}$ & $\begin{array}{c}\text { Festuca } \\
\text { Arundinacea }(F A) \\
\\
\text { Onobrychis } \\
\text { Viciifolia }(O V)\end{array}$ & $\begin{array}{c}\text { Festuca Arundinacea } \\
\text { Cr - } 17,1 \%, \\
\mathrm{Ni}, \mathrm{Cu}, \mathrm{Zn} \text { between } 29,4-39,1 \% \\
\mathrm{Fe}-\text { up to } 61,2 \% \\
\text { Onobrychis Viciifolia } \\
\mathrm{Cu}-59,3 \% \\
\mathrm{Cr}-29,9 \% \\
\mathrm{Ni}-42,2 \%\end{array}$ & [56] \\
\hline
\end{tabular}


As for the possibilities of using of the harvested biomass enriched with the metals species, this is for sure another very important research topic [57]. In this respect, research was conducted regarding the use of biomass in industrial combustion process. Within the experiments were used blends of biomass (sawdust) with different other materials such as coal, clay, ash, slag from various industrial power plants from Romania. The role of biomass was to improve the industrial combustion processes. The obtained experimental results led to the following main conclusions: a) when using of biomass waste mixed with coal, the carbon content and calorific values increased and the ash and Sulphur content decreased; b) wastes biomass added to coal and slag reduces the amount of ash and decreases the Sulphur content improving the process from the energetically point of view. So, these results can be used for further adjustments to the feed of some combustion power plants in order to be able to use biomass waste in their operations. Other types of waste having cellulose content are also subject to some new biotechnological solutions for transforming them in useful products. Thus, was studied the biogas production by using paper and mill organic sludge in combination with fermented municipal sludge and cattle manure as inoculum [58]. The experimental results showed that paper wastes can be used for biogas production by thermophilic anaerobic digestion $\left(50^{\circ} \mathrm{C}\right)$ for a retention time of 28 days. Even if biogas production is lower than in the case of anaerobic digestion of municipal sludge, this one is sufficient for biogas facility maintenance. Also, the anaerobically stabilized sludge can be used without any health risk, as agricultural fertilizer because potential pathogen bacteria are absent after digestion period. In the same idea were reported the results obtained by using anaerobically digested (stabilized) sewage sludge as fertilizer for corn culture [59]. A comparison between amounts of heavy metals that have been accumulated in different parts of the plant: grain, basal node, leaves, cobs and corn husks was carried out. The results showed that in the aerial parts of the harvested plants from fertilized fields with the sewage sludge, the toxic metals concentrations for $\mathrm{Cd}, \mathrm{Ni}, \mathrm{Cr}$, have been under the detection limits, and the amount of $\mathrm{Zn}$ was according to the nutritional requirements. In all studied cases, the heavy metals amounts were mostly bioaccumulate in the leaves of harvested plants. The heavy metals accumulated in grains were always lower than in aerial parts. This experimental research has been done in order to show how sludge, might be used as fertilizer on corn soil cultures in comparison with unfertilized corn soil cultures. Such, the anaerobically digested sewage sludge can contribute to an increase of corn production with $12 \%$ comparing to the amount harvested from the control field and with $5 \%$ comparing to the amount collected from a fertilized field with $40 \mathrm{t} / \mathrm{ha}$ of manure.

In the same category of using waste in agriculture, another example is to use the stabilized sewage sludge for obtaining compost type products [60]. In this respect, was performed several composting experiments using dewatered anaerobic digested sludge from a municipal WWTP (Waste Water Treatment Plant). As vegetal wastes, have been use vine shoots, straws and wood chips in different proportions and water for ensuring a $50-70 \%$ humidity. The process of composting evolution was verified during the whole period of three months by controlling specifically parameters. The quality of the obtained compost was similar to the commercial products used for pot-flowers. The heavy metal concentrations were below the limits imposed by Order 344/2004, which makes it possible soils fertilization with this composting recipe. In the domain of waste valorization, the composite materials have a special attention in the latest years. Next, in a series of papers are presented experimental researches in order to obtain and characterize new composite materials using different types of waste $[61-64,65,66]$. The role of these composite materials is to absorb and mitigate noise from industry or extra urban and urban areas. Thus, were established the specific parameters and proposed wastes compatibilities in order to obtained composite materials according to the absorption coefficient which recommends them from the point of view of other necessary characteristics depending on intended applications.

Different recipes for obtaining composite materials were tried by using different types of waste both as a binder matrix and as a reinforcing agent. Wastes from technological 
processes from different industries were used, such as metallurgical industry - steel slag waste, thermal power plants - ash, high temperature sterilized municipal waste, wood processing industries - wood waste of various sizes, industry rubber or automobiles - crushed rubber waste. The porosity of each material obtained is the main property for the absorption of sound waves but of course it is important and mechanical strength.

The obtained results are presented in Table 3 with reference to each proposed composite material related to the matrix binder and reinforcement agents, a part of used material being from processed waste.

Table 3. Waste derived composites, technical characteristics and possible uses

Composite material Characteristics Possible uses Ref.

Binder matrix: fly ash;

Reinforcement agents: slag steelworks, sterilized waste garbage, slag outbreak from thermal power plant, seed shells burning ash

Binder matrix: polyester resin $50 \%$; Reinforcement agents: rubber powder waste 50 $\%$ from used tires and from rubber formed polymer processing (natural styrene butadiene isoprene)

Binder matrix: formaldehyde resin; Reinforcement agents: waste slag, sterile municipal waste and sawdust

Binder matrix: formaldehyde resin $80 \%$

Reinforcement agents: ground glass, wood and polypropylene waste

Binder matrix: polymeric resins; Reinforcement agents: solid organic or inorganic wastes

Binder matrix: concrete mixes with different water to cement ratio $(0.45,0.50$ and 0.55$)$

Reinforcement agents: crumb rubber dosages $(0 \%, 5.0 \%$ and size ranging varied from 0.5 to 4 $\mathrm{mm})$ and it was used a fine aggregate with size ranging from 0.063 to $2 \mathrm{~mm}$, and a coarse aggregate with size ranging from 2 to $16 \mathrm{~mm}$
-Absorption coefficient of

0.98 in the frequency

range: $400 \div 2600 \mathrm{~Hz}$

absorbing panels

-Material of Class A

-Diffraction coefficient decreases proportionally with the increasing of the operation frequency.

-A reduction of sound pressure level due to absorptive properties.

absorption coefficient

between 0.8-0.9

panels for

industrial sound-

absorbing barriers

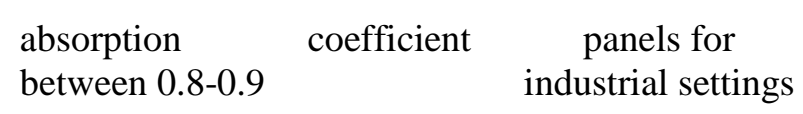

-good mechanical properties

(hardness, abrasion and

compressive strengths)

-good thermal stability at

high temperatures variation

and

panels for

-high stability in different

aggressive media

-good sound absorption capacity depending on the proportion and nature of used waste.

-good mechanical properties (hardness, abrasion and compressive strengths)

-good sound absorption capacity depending on the

panels for compozit material porosity industrial settings
Other research studies were focused on obtaining the plastics composite materials [67]. The used materials were mixtures of HDPE and PP with different filler contents of crushed postage envelope waste. The assessing mechanical and morpho-structural characteristics of these composite materials was realized with SEM (Scanning Electron Microscopy). The results shown that wastes of mixtures of paper and plastic can be competitive 
for obtaining plastic composite materials when special mechanical and electrical characteristics are not required.

Related to the same possible use, in another paper are presented the results of an investigation related to the assessment of the environmental impact at disposal of the abovementioned composite materials [68]. Thus, combined plastic and paper waste were subject to the leaching test before being injected in the matrices of composite materials and after applying this recovery process.

It is known that, when a recovery process is proposed, the new obtained products, besides compliance to the quality standards for their proposed use/application, should also meet the standards for the environmental quality. The results from leaching tests in accordance with Order 95/2005 show that after the wastes injection in the matrices of composite materials the concentrations of indicators as DOC (Dissolved Oxygen Carbon) and TDS (Total Dissolved Solids) are smaller than limits imposed comparing with wastes made of mixtures of plastics and paper. Thus, the obtained composite materials are recommended also from the environmental point of view.

In addition to the recovery of energy components from waste, energy recovery is another option that needs to be investigated before the final disposal of waste. For the correct operation of a combustion plant, the combustion characteristics of the fuel and fusion characteristic of the produced ash are very important. In this regard, the oxides composition from residual ashes and its influence on the

\section{CONCLUSIONS}

The research studies result from the present work, have been obtained within research projects and have been materialized in: pollutants detection and monitoring methods from complex matrices wastes, environmental impact and risk assessment methods, methodologies and models, waste hazardousness assessment and classification methodologies according to the harmonized European list, technological solutions for waste treatment, recycling and valorization.

Those results were the basis to develop some new environmental services for different economic agents, represented the basis for slagging and fouling process was studied [69]. The slag process was evaluated on the basis of indices such as: the basic oxides, the acid-base ratio, the slag index and the fouling index. The obtained results show that, depending on basic oxides, sewage ash can cause a high to moderate slagging tendency. Thus, the complete characterization of the sludge has an important role in the design of combustion plants for their incineration or co-incineration.

And last but not least we should mention that water quality is also vital for all the planet [70]. Consequently, in order to protect the good water quality, its recovery from the treatment of industrial liquid waste represent a necessity governed by present accelerated economic progress of the society. Thus, one study presents how two types of different wastes can be combined in order to clean an industrial wastewater heavily polluted. The paper presents the use of a coagulation agent obtained from industrial waste containing as a major component $\mathrm{Cu}, \mathrm{Mn}, \mathrm{Al}$ and $\mathrm{Fe}$ to treat wastewater from printing industry, replacing this way more costly usual used inorganic coagulants like $\mathrm{FeCl}_{3}$ and $\mathrm{AlCl}_{3}$. The results show that very heavily polluted liquid waste from printing industry was brought to a much lower pollution level, by a combined coagulation, precipitation and co-precipitation processes. The quality of the separated, filtrate can also be improved according to the further water use (industrial use) or for the discharge into a water body with or without final wastewater treatment plant according to the legally imposed limits.

applying them in other research projects and establishing the research partnerships with entities in the field of environmental protection. Waste management is a major and complex issue both in Romania and all over the world. All the research done in the past and the future research will have as priority finding those best solutions for minimizing the quantity of waste generated, as well as the treatment and safe disposal of hazardous waste. At the same time, research on best practices for the application of industrial symbiosis and the circular economy remains relevant for the entire scientific community. 


\section{ACKNOWLEDGEMENTS}

National Research and Development Institute for Industrial Ecology performed these researches with the financial support of the Romanian Research and Innovation Ministry and Union Europe in the period of 2009 - 2019 (NUCLEU Program, CEEX Program, LIFE+ Program, POC Program).

\section{REFERENCES}

[1] Commission Decision 2000/532/EC of 3 May 2000 replacing Decision 94/3/EC establishing a list of wastes pursuant to Article 1(a) of Council Directive 75/442/EEC on waste and Council Decision 94/904/EC establishing a list of hazardous waste pursuant to Article 1 (4) of Council Directive 91/689/EEC on hazardous waste.

[2] Regulation (EC) No 1907/2006 of the European Parliament and of the Council of 18 December 2006 concerning the Registration, Evaluation, Authorization and Restriction of Chemicals (REACH), establishing a European Chemicals Agency, amending Directive 1999/45/EC and repealing Council Regulation (EEC) No 793/93 and Commission Regulation (EC) No 1488/94 as well as Council Directive 76/769/EEC and Commission Directives 91/155/EEC, 93/67/EEC, 93/105/EC and 2000/21/EC.

[3] Directive 2008/98/EC of the European Parliament and of the Council of 19 November 2008 on waste and repealing certain Directives.

[4] Regulation (EC) No 1272/2008 of the European Parliament and of the Council of 16 December 2008 on classification, labeling and packaging of substances and mixtures, amending and repealing Directive 67/548/EEC and 1999/45/EC and amending Regulation (EC) No $1907 / 2006$.

[5] Commission Regulation (EU) No 1357/2014 of 18 December 2014 replacing Annex III to Directive 2008/98/EC of the European Parliament and of the Council on waste and repealing certain Directives.

[6] Commission notice on technical guidance on the classification of waste $(2018 / \mathrm{C} 124 / 01)$.

[7] TEH, T., NIK NORULAINI, N. A. R., SHAHADAT, M., WONG, Y., MOHD OMAR, A.K., Pedosphere., 26, no. 4, 2016, p. 431.

[8] HABIB, K., SCHMIDT, J.H., CHRISTENSEN, P., Waste Manage., 33, no. 9, 2013, p. 1926.

[9] STANISAVLJEVIC, N., BRUNNER, P.H., Waste Manag. Res., 38, no. 6, 2020, p. 597.
[10] SUN, W., XU, X., LV, Z., MAO, H., WU,

J., J. Environ. Manage., 245, 2019, p. 210.

[11] DING, F., Procedia Environ. Sci., 13, 2012, p.1149.

[12] SHI, L., YIN, Y., ZHANG, L.C., WANG, S., SILlANPAA, M., Sun, H., Appl. Catal. BEnviron., 248, 2019, p. 405.

[13] PATIL, Y. P., PAWAR, S.H., JADHAV, S., KADU, J.S., Int. J. Sci. Res. Publ., 3, no. 4, 2013, p. 1.

[14] Law No 211/2011 from 15 Nov. 2011 about waste regime [in Romanian].

[15] PUIU, D., CRUCERU, L.V., Proceedings of $19^{\text {th }}$ International Symposium "The Environment and the Industry", Bucharest, 1314 October 2016, p. 81, http://doi.org/10.21698/simi.2016.0009.

[16] EN 16457:2014 Characterization of waste Framework for the preparation and application of a testing program - Objectives, planning and report.

[17] HENNEBERT, P., PAPIN, A., PADOX, J. M., HASEBROUCK, B., Waste Manage., 33, no. 7, 2013, p. 1577.

[18] DEFOREST, D.K., BRIX, K.V., ADAMS, W.J., Aquat. Toxicol., 84, no. 2, 2007, p.236.

[19] KIM, L., CATRINA (TRAISTARU), G.A., STANESCU, B., PASCU, L.F., GHEORGHITA, T., MANOLACHE, D., Rev. Chim., 70, no.1, 2019, p. 269.

[20] KIM, L., MURESAN, A-M., CUCIUREANU, A., GUTA, D., ARAMA, M., CRISTEA N. I., DEDIU, V., Proceedings of $20^{\text {th }}$ International Symposium "The Environment and The Industry", Bucharest, Romania, 28-29 September 2017, p.143, http://doi.org/10.21698/simi.2017.0018.

[21] CATRINA (TRAISTARU), G.A., SERBANESCU, A., BARBU, M., NICOLESCU, I., CRISTEA, N.I., STANESCU, B., COVAlIU, I. C., Proceedings of $21^{\text {th }}$ International Symposium "The Environment and the Industry", Bucharest, Romania, 20-21 September 2018, p. 347, http://doi.org/10.21698/simi.2018.fp41. 
[22] BARBU, M., SERBANESCU, A., NICOLESCU, I., BUCUR, E., Proceedings of $19^{\text {th }}$ International Symposium "The Environment and The Industry", Bucharest, Romania, 13-14 October 2016, p. 389, http://doi.org/10.21698/simi.2016.0054.

[23] NICOLESCU, I.C., BUCUR, E., SERBANESCU, A., DIODIU, R., BARBU, M., Proceedings of $20^{\text {th }}$ International Symposium "The Environment and the Industry", Bucharest, Romania, 28-29 September 2017, p. 242, http://doi.org/10.21698/simi.2017.0031.

[24] PATRICIO, J., KALMYKOVA, Y., ROSADO, L., J. Clean. Prod., 246, 2020, p. 1.

[25] SOWKA, I., MILLER, U., GRZELKA, A., Environ. Prot. Eng. 43, no. 4, 2017, p. 233.

[26] VALLERO, A.D., Something in the air in Paradigms Lost: Learning from Environmental Mistakes, Mishaps, and Misdeeds, Elsevier Inc., USA, 2006, p. 109-157.

[27] MOTALEBI DAMUCHALI, A., GUO, H., Biosyst. Eng. 187, 2019, p. 239.

[28] ANDREI, V., DANCIULESCU, V., GEHORGHITA, T., KIM, L., DEDIU, V., Rev. Chim., 68, no. 8, 2017, p.1749.

[29] STANESCU, B., PETRESCU, M., BATRINESCU, G., Proceedings of $16^{\text {th }}$ International Symposium "The Environment and the Industry", Bucharest, Romania, 16-18 November 2011, p. 20.

[30] STANESCU, B., PETRESCU, M., BATRINESCU, G., J. Environ. Prot. Ecol. 13, no. 4, 2012, p. 2145.

[31] STANESCU, B., PETRESCU, M., BATRINESCU, G., First International Conference on Moldavian Risks -From Global to local scale, Bacau, Romania, 16-19 May 2012, p.1.

[32] PETRESCU, M., CALINESCU, S., STANESCU, B., BARSAN, E., LUCACIU, I., GHEORGHE S., Proceedings of $16^{\text {th }}$ International Symposium "The Environment and the Industry", Bucharest, Romania, 16-18 November 2011, p. 40.

[33] CUCIUREANU, A., BATRINESCU, G., STANESCU, B., DUMITRACHE, R., Proceedings of $17^{\text {th }}$ International Symposium "The Environment and the Industry", Bucharest, Romania, 28-30 October 2013, p. 253.

[34] CUCIUREANU, A., KIM, L., LEHR. C. B., ENE, C., Rev. Chim., 68, no. 8, 2017, p. 1695.
[35] ARAMA, M., GHEORGHE, V.A., RADU, C., STANCIU, R.D, NICOLAU, M., Rev. Manag. Ing. Ec., 9, 2010, p. 37.

[36] ARAMA, M., STANCIU R., NICOLAU M., $2^{\text {nd }}$ Review of Management and Economic Engineering (RMEE), Tech. Univ. Cluj Napoca, Romania, 15-17 September 2011, p. 8.

[37] ARAMA, G.M., ANGHEL, A., CRISTE V., Met. Int., 18, 12, 2013, p. 111.

[38] ARAMA, G.M., PASCU, L.F., GUTA, D., Proceedings of $18^{\text {th }}$ International Symposium "The Environment and The Industry", Bucharest, Romania, 29-30 October 2015, p. 118, http://doi.org/10.21698/simi.2015.0013.

[39] ARAMA, G.M., KIM, L., Proceedings of $19^{\text {th }}$ International Symposium "The Environment and The Industry", Bucharest, Romania, 13-14 October 2016, p. 66, http://doi.org/10.21698/simi.2016.0007.

[40] ARAMA, G.M., PASCU, L.F., LEHR, C., Environ. Eng. Manag. J., 16, no. 5, 2017, p. 1217.

[41] ARAMA, G.M., KIM, L., GUTA, D., Proceedings of $20^{\text {th }}$ International Symposium "The Environment and The Industry", Bucharest, Romania, 28-29 September 2017, p. 151, http://doi.org/10.21698/simi.2017.0019.

[42] ARAMA, G.M., PASCU, L.F., LEHR, C., Environ. Eng. Manag. J., 17, no. 9, 2018, p. 1217.

[43] ARAMA, G.M., KIM, L., CUCIUREANU, A., SERBANESCU, A., NICOLESCU, I., BARBU M., STANESCU, B., TRAISTARU, G., Proceedings of $21^{\text {th }}$ International Symposium "The Environment and The Industry", Bucharest, Romania, 20-21 September 2018, p. 1843, http://doi.org/10.21698/simi.2018.fp25.

[44] KIM, L., ARAMA, G.M., Environ. Eng. Manag. J., 17, no. 9, 2018, p. 2201.

[45] LEHR, C., MANDRICELU, C., PETRESCU, M., Proceedings of $16^{\text {th }}$ International Symposium "The Environment and the Industry", Bucharest, Romania, 16-18 November 2011, p. 28.

[46] GUTA, D., BATRINESCU, G., CUCIUREANU, A., Proceedings of $17^{\text {th }}$ International Symposium "The Environment and the Industry", Bucharest, Romania, 28-30 October 2013, p. 243.

[47] GUTA, D., ARAMA, G.M., STANESCU, B., BATRINESU, G., LEHR, C.B., Proceedings of International Congress on "Green 
infrastructure and Sustainable Societies/Cities" GreInsu'14s, Izmir, Turkey, 08 May 2014, p. 82. [48] GUTA, D., CUCIUREANU, A., KIM, L., ARAMA, M., Proceedings of $20^{\text {th }}$ International Symposium "The Environment and the Industry", Bucharest, Romania, 28-29 September 2017, p. 189, http://doi.org/10.21698/simi.2017.0024.

[49] KIM, L., ARAMA, G.M., CUCIUREANU, A., GUTA, D., Environ. Eng. Manag. J., 17, 12, 2018, p. 2945.

[50] NEVES, A., GODINA, R., AZEVEDO, S.G., MATIAS JOAO, C.O., J. Clean. Prod., 247, 2020, p. 1.

[51] CONSTANTIN, L., TEORDORESCU, C., Proceedings of $16^{\text {th }}$ International Symposium "The Environment and the Industry", Bucharest, Romania, 16-18 November 2011, p. 285.

[52] TEORDORESCU, C., CONSTANTIN, L., STEFANESCU, B., NICOLAU, M., Proceedings of $16^{\text {th }}$ International Symposium "The Environment and the Industry", Bucharest, Romania, 16-18 November 2011, p. 269.

[53] CONSTANTIN, M.A., BATRINESCU, G., CRISTEA, I., BADESCU, V. R., Proceedings of $19^{\text {th }}$ International Symposium "The Environment and the Industry", Bucharest, Romania, 13-14 October 2016, p. 409, https://doi.org/10.21698/simi.2016.0057.

[54] MASU, S., POPA, M., MORARIU, F., Proceedings of $18^{\text {th }}$ International Symposium "The Environment and the Industry", Bucharest, Romania, 29-30 October 2015, p. 186.

[55] MASU, S., BURTICA, G., JURJ, N.L., ALBULESCU, M., Studia UBB Chemia, LVII, no. 3, 2012, p. 249.

[56] MASU, S., RUS, V., J. Environ. Prot. Ecol., 14 no.1, 2013, p. 204.

[57] BARBU, M., BUCUR, E., NICOLESCU, I., VASILE, A., DASCALU, C., Proceedings of $16^{\text {th }}$ International Symposium "The Environment and the Industry", Bucharest, Romania, 2011, p. 119.

[58] BUMBAC, C., PENA LEONTE, E., DUMITRESCU, E. C., TEODORESCU, C., J. Environ. Prot. Ecol., 11, no. 1, 2010, p. 209.

[59] MORARIU, F., LIXANDRU, B., MASU, S., POPESCU, D., J. Anim. Sci. Biotechnol., 41, no.1, 2014, p. 177.
[60] PATROESCU, V., DINU, L., BUMBAC, C., PENA LEONTE, E., Proceedings of $16^{\text {th }}$ International Symposium "The Environment and the Industry", Bucharest, Romania, 16-18 November 2011, p. 147.

[61] BRATU, M., DUMITRESCU, O., VASILE, O., BUCUR, E., Proceedings of $17^{\text {th }}$ International Symposium "The Environment and the Industry", Bucharest, Romania, 28-30 October 2013, p. 199.

[62] BRATU, M., VASILE, A., Proceedings of $16^{\text {th }} \quad$ International Symposium "The Environment and the Industry", Bucharest, Romania, 16-18 November 2011, p. 209.

[63] BRATU, M., ROPOTA, I., VASILE, O., DUMITRESCU, O., MUNTEAN, M., Rev. Rom. Mater., 41, no.1, 2011, p. 22.

[64] BRATU, M., DUMITRESCU, O., VASILE, O., CONSTANTIN (CRISTEA), A., MUNTEAN, M., Rev. Rom. Mater., 44, no.2, 2014, p.160.

[65] ROPOTA, I., BRATU, M., DRAGNEA, D., DUMITRESCU, O., MUNTEAN, O., MUNTEAN, M., Studia UBB Chemia, LVIII, no. 4, 2013, p. 213.

[66] GHIADAVET, Z., STEFAN, B.M., NASTAC, D., VASILE, O., BRATU, M., Constr. Build. Mater., 124, 2016, p. 755.

[67] CIOBANU, R.C., BATRINESCU, G., URSAN, G. A., CARAMITRU, A.R., MARINESCU, V., BORS, A.M., LINGVAY, I., Mater. Plast., 55, no. 3, 2019, p. 475.

[68] BATRINESCU, G., CRISTEA, I.N., BADESCU, R.V., CIOBANU, R.C., URSAN, G.A., ARADOAEI, M., Rev. Chim., 70, no. 12, 2019, p. 4579.

[69] SERBANESCU, A., BARBU, M., CRISTEA, I., CATRINA, G., CERNICA, G., STEFANESCU, M., BERCU, O., Proceedings of $22^{\text {nd }}$ International Symposium "The Environment and The Industry", Bucharest, Romania, 26-27 September 2019, p. 184, http://doi.org/10.21698/simi.2019.fp24.

[70] PASCU, L.F., ANDRES, L., MASU, S., Proceedings of $20^{\text {th }}$ International Symposium "The Environment and the Industry", Bucharest, Romania, 28-29 September 2017, p. 22, http://doi.org/10.21698/simi.2017.0002. 